\title{
Geniposide Prevents Hypoxia/ Reoxygenation-Induced Apoptosis in H9c2 Cells: Improvement of Mitochondrial Dysfunction and Activation of GLP-1R and the PI3K/AKT Signaling Pathway
}

\author{
You-Qin Jiang Guang-lei Chang Ying Wang Dong-Ying Zhang Li Cao Jian Liu \\ Department of Cardiology, First Affiliated Hospital of Chongqing Medical University, Chongqing Key \\ Laboratory of Ophthalmology, Chongqing, China
}

\author{
Key Words \\ Geniposide • Hypoxia/reoxygenation • Cardiomyocyte apoptosis • Mitochondria • GLP-1R
}

\begin{abstract}
Background/Aims: Myocardial ischemia/reperfusion injury is a major cause of morbidity and mortality associated with coronary heart disease. Many studies have demonstrated that natural products are promising chemotherapeutic drugs counteracting the loss of cardiomyocytes. Thus, the purpose of the present study was to investigate the effects of geniposide, a traditional Chinese herb extract from Gardenia jasminoides J. Ellis, on cardiomyocyte apoptosis induced by hypoxia/reoxygenation $(H / R)$ in $H 9 c 2$ cells, and their underlying mechanisms. Methods: Cell viability and apoptosis ratio were assessed using the cell counting kit- 8 assay and Annexin V/propidium iodide (PI) staining. The concentrations of lactate dehydrogenase $(\mathrm{LDH})$, intracellular total superoxide dismutase (T-SOD), and malondialdehyde (MDA) were detected by microplate reader. The production of reactive oxygen species/reactive nitrogen species (ROS/RNS), the level of mitochondrial calcium, and mitochondrial membrane potential depolarization were measured by confocal laser scanning microscopy. Mitochondrial morphology was visualized using transmission electron microscopy. The expressions of $\mathrm{Bcl}-$ 2 mRNA and Caspase-3 mRNA were measured by reverse transcription-polymerase chain reaction (RT-PCR). The protein levels of cleaved caspase-3, Bcl-2, Bax, AKT, p-AKT ${ }^{\text {serine473, }}$ cytochrome-c were detected by western bloting. Results: Geniposide pretreatment increased cell viability, decreased LDH levels in the supernatant, and inhibited cardiomyocyte apoptosis caused by $\mathrm{H} / \mathrm{R}$. Furthermore, geniposide reversed mitochondrial dysfunction by decreasing oxidative stress products (ROS/RNS and MDA), increasing anti-oxidative enzyme (T-SOD) level, improving mitochondrial morphology, attenuating mitochondrial calcium overload and blunting depolarization of mitochondrial membrane. Moreover, geniposide pretreatment increased $\mathrm{BCl}-2$ level and decreased $\mathrm{Bax}$ level, thus enhancing the $\mathrm{BCl}-2 / \mathrm{Bax}$ ratio. Consistent
\end{abstract}

Jian Liu

KARGER
Department of Cardiology, First Affiliated Hospital of Chongqing Medical University No. 1, You Yi Road, Yuan Jia Gang, Yu Zhong District, 400016 Chongqing, (China) Tel. 13996609872, E-Mail liujian819@126.com 
with the above result, $\mathrm{Bcl}-2$ mRNA expression was upregulated and caspase- 3 mRNA expression was downregulated by geniposide. In addition, geniposide decreased the protein expression of cleaved caspase-3 and cytochrome-c and increased the level p-AKTserine473. The protective effects of geniposide were partially reversed by glucagon-like pepitide-1 receptor antagonist exendin-(9-39) and the phosphatidylinositol 3 kinase (PI3K) inhibitor LY294002. Conclusions: Our results suggest that geniposide pretreatment inhibits H/R-induced myocardial apoptosis by reversing mitochondrial dysfunction, an effect in part due to activation of GLP-1R and PI3K/ AKT signaling pathway.

\section{Introduction}

Currently, ischemia heart disease is an overwhelming health burden worldwide [1, 2]. Cardiomyocyte apoptosis caused by ischemia/reperfusion (I/R) injury can lead to myocardial cell loss, which further accelerates cardiac dysfunction, ventricular remodeling, and even heart failure [3-6]. Numerous studies have reported that inhibition of apoptosis could attenuate myocardial damage, decrease cardiomyocyte removal, and improve ventricular contractile function caused by I/R [7]. Cardiomyocyte apoptosis includes two major pathways, the extrinsic pathway via death receptors, and the intrinsic pathway involving mitochondria $[8,9]$. Notably, the mitochondria-dependent pathway plays a key role in I/R-induced myocardial cell apoptosis $[3,4,10]$. The most typical characteristic of myocardial ischemia is severe hypoxia, which could cause acidosis, energy depletion, and ion homeostasis rupture, ultimately resulting in cardiomyocyte death [11]. Mitochondria are abundant in myocardial cells and are responsible for energy metabolism by utilizing oxygen, and they are undoubtedly involved in the pathophysiological changes that occur during I/R injury. Successful reperfusion, is absolutely necessary to reduce the infarct area of the heart. However, reperfusion also generates abundant products of oxidative stress, such as reactive oxygen species/reactive nitrogen species (ROS/RNS), which could trigger mitochondrial oxidative stress, mitochondrial calcium overload, and mitochondrial membrane depolarization, leading to opening of the mitochondrial permeability transition pore (mPTP), release of large pro-apoptosis proteins, cardiomyocyte apoptosis, and death $[8,12-14]$. Therefore, inhibition of mitochondrial oxidative stress during the I/R process might be a key therapeutic approach.

Gardenia jasminoides J. Ellis, a kind of traditional Chinese herb, has extensive pharmacological actions in the treatment of inflammation, hepatic disorders and hypertension. Geniposide, an extract of Gardenia jasminoides J. Ellis and a novel agonist for glucagon-like peptide-1 receptor (GLP-1R), has been shown to exert antinociception effects [15], promote $\beta$-cell regeneration, attenuate $\beta$-cell apoptosis $[16,17]$, regulate insulin secretion in INS-1 cells [18], and prevent oxidative stress of PC12 cell [19]. Accumulating evidences has revealed that glucagon-like peptide 1 (GLP-1) and GLP-1 analogues exert anti-apoptotic effects by activating GLP-1R via the phosphatidylinositol 3 kinase (PI3K)/ AKT signaling pathway [3, 20-22]. Geniposide can also activate GLP-1R in response to oxidative stress in PC12 cells via the PI3K/AKT pathway [23], inhibit PC12 cell death by the mitochondrial pathway [24], and attenuate memory deficits in amyloid precursor protein (APP)/ presenilin 1(PS1) transgenic mice by improving mitochondrial dysfunction [25]. Nevertheless, the effects of geniposide on the cardiovascular system are poorly understood.

To mimic myocardial I/R injury, we established a hypoxia/reoxygenation (H/R) model in H9c2 cells. In this study, we investigated the protective effect of geniposide in cardiomyocytes against H/R-induced apoptosis, and whether the mechanism involved improving mitochondrial dysfunction, and activating GLP-1R and PI3K/AKT pathway. 
Jiang et al.: Geniposide Prevents Hyposia/ Reoxygenation-Induced Apoptosis In H9c2 cells

\section{Materials and Methods}

\section{Cell culture and establishment of $H / R$ model}

H9c2 cell line (Guangzhou Jenniobio Biotechnology Co., Ltd, Guangzhou, China) was cultured in Dulbecco's Modified Eagle's Medium/Nutrient Mixture F-12 (DMEM/F12, Thermo Fisher Biochemical Products, Beijing, China) supplemented with $10 \%$ (v/v) fetal bovine serum (FBS, Invitrogen Life Technologies, Carlsbad, CA, USA), $100 \mu \mathrm{g} / \mathrm{mL}$ of penicillin and $100 \mu \mathrm{g} / \mathrm{mL}$ of streptomycin (both from Beyotime Institute of Biotechnology, Shanghai, China). Cells were cultured to 70-80\% confluence in diverse culture dishes with humidified air $\left(5 \% \mathrm{CO}_{2}, 21 \% \mathrm{O}_{2}\right)$ at $37^{\circ} \mathrm{C}$. To establish the hypoxia condition of the $\mathrm{H} / \mathrm{R}$ model, cells were subjected to hypoxia using glucose-free and FBS-free DMEM/F12 buffer in a hypoxia chamber (Thermo Forma, Thermo Fisher Scientific, Boston, MA, USA) suffused with $94 \% \mathrm{~N}_{2}, 5 \% \mathrm{CO}_{2}$ and $1 \% \mathrm{O}_{2}$ at $37^{\circ} \mathrm{C}$. The medium was then transferred to $10 \%$ FBS DMEM/F12 in normal conditions for reoxygenation.

\section{Cell viability assay}

H9c2 cells were seeded at a density of $5 \times 10^{3}$ cells/well in 96-well plates containing $100 \mu$ medium in each well for $24 \mathrm{~h}$, and subsequently exposed to H/R (H/R time: 4/2, 6/3, 12/4, 14/5, 16/6, 22/10 h). Cell viability was evaluated with the cell counting kit-8 (CCK-8, Beyotime Institute of Biotechnology, Shanghai, China) by a microplate reader (Multiskan MK33, Thermolab Systems, Helsinki, Finland) at a wavelength of $450 \mathrm{~nm}$. The available H/R time was set according to the results of cell viability. The above experiment was repeated six times.

H9c2 cells were pretreated with or without geniposide (ChromaDex ${ }^{\circledast}$ Corporate Heaquart, Irvine, CA, USA) in gradient concentrations of $2.5,5,10,20,40,80,160$, and $320 \mu \mathrm{M}$ for $30 \mathrm{~min}$ before exposed to $\mathrm{H} / \mathrm{R}$ (available H/R time). Geniposide was dissolved in double distilled water. To select available concentration of geniposide, the cell viability was evaluated with CCK-8, and the optical density was tested by microplate reader at $450 \mathrm{~nm}$ wavelength. The above experiments were repeated six times.

H9c2 cells were divided into eight groups: 1) Control group, cells were cultured under normal conditions. 2) Geniposide group, cells were cultured with available concentration of geniposide under normal conditions. 3) Control + L, cells were cultured with LY294002 (15 $\mu \mathrm{M})$ under normal conditions. 4) Control +E, cells were cultured with exendin (9-39) (200 nM) under normal conditions.5) H/R group, cells were subjected to hypoxia/ reoxygenation (available H/R time). 6) H/R + Geniposide (G) group, cells were pretreated with geniposide for 30 min and then exposed to H/R. 7) H/R + G + L group, cells were pretreated with LY294002 (15 $\mu \mathrm{M})(\mathrm{L})$ for $30 \mathrm{~min}$, incubated with G for $30 \mathrm{~min}$, and then subjected to H/R. 8) H/R + G + E group, cells were pretreated with exendin (9-39) (200 nM) (E) for $30 \mathrm{~min}$, incubated with G for $30 \mathrm{~min}$, and then subjected to $\mathrm{H} / \mathrm{R}$.

\section{Determination of apoptosis ratio}

Cells $\left(1.3 \times 10^{5}\right)$ were seeded in six-well plates for $24 \mathrm{~h}$. Following different treatments, cells of each group were collected, washed with phosphate-buffered saline (PBS) twice, and resuspended at a density

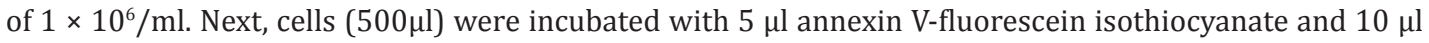
propidium iodide (PI, $20 \mu \mathrm{g} / \mathrm{mL}$ ) for $15 \mathrm{~min}$ in the dark at room temperature. The fluorescence intensities of annexin V/PI-stained cells were analyzed by flow cytometry within $1 \mathrm{~h}$. Flow cytometric analysis (Ex. $488 \mathrm{~nm} / \mathrm{Em} .530 \mathrm{~nm}$ ) was performed with BD Influx cell sorter (BD Biosciences, San Jose, CA, USA). The apoptotic cells, including annexin $\mathrm{V}+/ \mathrm{PI}-$ were counted. The apoptosis ratio was quantified by BD FACS software. The above experiment was repeated three times.

Lactate dehydrogenase (LDH), total superoxide dismutase (T-SOD) and malondialdehyde (MDA) detection The levels of LDH in cell supernatants, and total intracellular levels of T-SOD and MDA in H9c2 cells were detected using commercially available kits according to the manufacturer's instructions (Jiancheng Bioengineering Institute, Nanjing, China). Briefly, cell supernatants were collected, mixed with reagents of the LDH assay kit, and incubated at room temperature for $5 \mathrm{~min}$, absorbance value of LDH was detected at $450 \mathrm{~nm}$ by microplate reader. LDH level was expressed as (U/L) according to the absorbance value reduction formula. After cell supernatants were removed, cells were lysed by Ultrasonic crusher at $300 \mathrm{~W}$ power under ice-water bath. After $30 \mathrm{sec}$, cells were crushed 3 to 5 seconds, and steps above were repeated five times. To calculate the concentration of MDA and T-SOD, protein concentrations of lysis buffer were measured by 


\section{Cellular Physiology Cell Physiol Biochem 2016;39:407-421 \\ \begin{tabular}{cc|c} 
DOI: 10.1159/000445634 & $\begin{array}{l}\text { O } 2016 \text { The Author(s). Published by S. Karger AG, Basel } \\
\text { www.karger.com/cpb }\end{array}$
\end{tabular}}

Jiang et al.: Geniposide Prevents Hyposia/ Reoxygenation-Induced Apoptosis In H9c2 cells

enhanced bicinchoninic acid (BCA) protein assay kit (Beyotime Institute of Biotechnology, Shanghai, China). To detect T-SOD levels, the cell lysis buffers were incubated with reagents of the T-SOD kit at $37^{\circ} \mathrm{C}$ for 20 min, T-SOD value was examined at $450 \mathrm{~nm}$ using a microplate reader and are expressed as $\mathrm{U} /$ (mg protein). To detect MDA, the cell lysis buffers were incubated with reagents of the MDA assay kit and boiled at $95^{\circ} \mathrm{C}$ for $40 \mathrm{~min}$, MDA value was determined at $530 \mathrm{~nm}$ and are expressed as $\mathrm{nmol} /(\mathrm{mg}$ prot). LDH level were measure six times. T-SOD and MDA detection was repeated three times.

Transmission electron microscope

The cells $\left(6 \times 10^{5}\right)$ were planted in culture bottles. After grown 70-80\%, each group of cells was cultured in the relevant treatment. Cells were washed, digested, centrifugalized, collected, and then fixed by $2.5 \%$ glutaraldehyde (Shanghai Junrui Biological Technology Co. Ltd, Shanghai, China) for $2 \mathrm{~h}$. After washing three times with cold PBS, each group of cells was fixed with 1\% osmium tetroxide (Shanghai Junrui Biological Technology Co. Ltd) for 15min. Next, each group of cells were embedded in EPON812 (Shanghai Easy Micro Mdt InfoTech Ltd, Shanghai, China) following dehydration in an ascending series of acetone ( $50 \%$ acetone for $10 \mathrm{~min}, 70 \%$ acetone for $10 \mathrm{~min}, 90 \%$ acetone for $10 \mathrm{~min}$, and $100 \%$ acetone for $10 \mathrm{~min}$ ). Finally, the specimens were cut into $1 \mu \mathrm{m}$ sections, and the sections were stained with sodium acetate (Shanghai Junrui Biological Technology Co. Ltd) and lead citrate (Beijing Economy Instruments Science \& Technology Co. Beijing, China). Ultrathin sections were examined with a transmission electron microscope (Hitachi-7500, Tokyo Japan). The above experiment was repeated three times.

\section{Confocal laser scanning microscopy}

ROS/RNS production, mitochondrial calcium concentration and depolarization ratio of mitochondrial membrane potential were measured by confocal laser scanning microscopy (Nikon, A1+R, Tokyo, Japan) with a 2', 7'-dichlorodihydrofluorescein diacetate (DCFH-DA) probe, a dihydroethidium (DHE) probe, a Rhod-2 AM probe, and a JC-1 probe (all from Beyotime Institute of Biotechnology), respectively. Cell $\left(1 \times 10^{5}\right)$ were seeded in a confocal dish (cover glass bottom dish) for $24 \mathrm{~h}$ under normal conditions, and then preincubated with geniposide for $30 \mathrm{~min}$ followed by H/R. After the cultivation mentioned above, the supernatants were discarded, and cells were respectively loaded with DCFH-DA (10 $\mu \mathrm{M})$, DHE (5 $\mu \mathrm{M})$, Rhod-2 AM (2 $\mu \mathrm{M})$, and $\mathrm{JC}-1$ ( $5 \mu \mathrm{g} / \mathrm{ml}$ ) at $37^{\circ} \mathrm{C}$ for $20 \mathrm{~min}, 30 \mathrm{~min}, 30 \mathrm{~min}$, and $25 \mathrm{~min}$. DCFH-DA (green fluorescence) was excited at $488 \mathrm{~nm}$ and emitted at $525 \mathrm{~nm}$. DHE (red fluorescence) was excited at $535 \mathrm{~nm}$ and emitted at $610 \mathrm{~nm}$. Rhod2 AM (blue fluorescence) was excited at $543 \mathrm{~nm}$ and emitted at $560 \mathrm{~nm}$. JC-1 monomer (green fluorescence) was excited at $514 \mathrm{~nm}$ and emitted at $529 \mathrm{~nm}$. JC-1 aggregate (red fluorescence) was excited at $585 \mathrm{~nm}$ and emitted at $590 \mathrm{~nm}$. The above experiment was repeated three times.

Cell RNA extraction and real-time reverse transcriptase polymerase chain reaction (RT-PCR)

All reagent kits of real-time RT-PCR were purchased from TaKaRa Biotechnology (Dalian, China). Total RNA was isolated from H9c2 cells using RNAiso Plus, and the concentrations of RNA and cDNA were determined using an ultraviolet spectrophotometer (Olympus, Tokyo, Japan). PrimeScript ${ }^{\circledR}$ RT reagent Kit was used to synthesize cDNA and the reaction volume $(20 \mu \mathrm{l})$ contained $4 \mu \mathrm{l} 5 \times$ PrimeScript $^{\circledR}$ Buffer, $1 \mu \mathrm{l}$ PrimeScript ${ }^{\circledast}$ RT Enzyme MixI, $1 \mu \mathrm{l}$ oligo dT primer, $1 \mu \mathrm{l}$ random 6 mers, $2 \mu \mathrm{l}$ total RNA, and $11 \mu \mathrm{l}$ RNase free $\mathrm{dH}_{2} \mathrm{O}$. Reverse transcription parameters were as follows: $37^{\circ} \mathrm{C} 15 \mathrm{~min}$ (reverse transcription reaction) and $85^{\circ} \mathrm{C} 5 \mathrm{sec}$ (decreasing activity of the reverse transcriptase). Then $2 \mu \mathrm{l} \mathrm{cDNA}$ template $(50 \mathrm{ng} / \mu \mathrm{l}$ ) was reacted with $12.5 \mu \mathrm{ISYBR}^{\circledast}$ Premix Ex Taq ${ }^{\mathrm{TM}} \mathrm{II}, 1 \mu \mathrm{l}$ of each primer $(10 \mu \mathrm{M})$, and $8.5 \mu \mathrm{l} \mathrm{dH}_{2} \mathrm{O}$ using ABI PRISM 7500 real-time PCR system (Applied Biosystems, Foster City, CA, USA). Primers were synthesized by TaKaRa Biotechnology and were as follows: 5' GGAGGAACTCTTCAGGGATGG 3' and 5' AGATGCCGGTTCAGGTACTCAG 3' for Bcl-2; 5' GAACGGACCTGTGGACCTGA 3' and 5' TGAATGATGAAGAGTTTCGGCT 3' for caspase-3. The above experiment was repeated three times.

\section{Mitochondrial and cytosolic protein fractionation}

In order to detect the release of cytochrome $\mathrm{C}$ from mitochondria to cytosol, mitochondria and cytosol were isolated using the Cell Mitochondria Isolation Kit (Abcam, ab110170, Cambridge, UK). Cells were digested and collected by centrifugation at $800 \mathrm{~g}$ for $5 \mathrm{~min}$, frozen and thawed to weaken the membranes, and then resuspended in reagent $\mathrm{A}(5 \mathrm{mg} / \mathrm{ml})$ on ice for $10 \mathrm{~min}$. The cell suspension was homogenizaed with 30 strokes using a pestle on ice. The homogenate was centrifuged at $800 \mathrm{~g}$ for $10 \mathrm{~min}$ at $4^{\circ} \mathrm{C}$ to 

cells

remove large particles. The supernatant was centrifuged and collected at $12000 \mathrm{~g}$ for $30 \mathrm{~min}$ at $4^{\circ} \mathrm{C}$ to isolate the cytosol (suspernatant) and mitochondria (pellet) fractions. Sample protiens of the cytosolic and mitochondrial fractions were extrated using radioimmunoprecipitation assay (RIPA) lysis buffer and reagent $\mathrm{C}$, respectively, and then subjected to western blotting.

\section{Western blot analysis}

H9c2 cells of each group were washed with PBS twice, and then mixed with mixed lysate buffer containing phenylmethanesulfonyl fluoride (PMSF) $(1: 1,000)$ and RIPA lysis buffer. Cell lysates were collected by centrifugation at $12,000 \mathrm{~g}$ for $15 \mathrm{~min}$ at $4^{\circ} \mathrm{C}$. The supernatant was collected and boiled for $5 \mathrm{~min}$, and then combined with sodium dodecyl sulfate polyacrylamide gel electrophoresis (SDS-PAGE) sample loading buffer. The protein concentrations of supernatant were measured using an enhanced BCA protein assay kit. Protein $(50 \mu \mathrm{g})$ resolved by SDS-PAGE and transferred to PVDF membranes. Membranes were blocked in 5\% nonfat milk for $2 \mathrm{~h}$. The membranes were then incubated with primary antibody (anticytochrome-c antibody (1:1500, Abcam, Cambridge, UK), anti-COX IV antibody (1:2,000, Abcam, Cambridge, UK), anti-cleaved caspase-3 antibody, anti-Bax antibody, anti-Bcl-2 antibody, anti-AKT antibody, antiphospho-AKT ${ }^{\text {serine473 }}$ (1:1,000, Cell Signaling Technology, Inc., Beverly, MA, USA), and anti- glyceraldehyde-3phosphate dehydrogenase (GAPDH) antibody (1:1,000, Beyotime Institute of Biotechnology)) overnight at $4^{\circ} \mathrm{C}$ and then incubated with horseradish peroxidase (HRP)-conjugated goat anti-rabbit or HRP-conjugated goat anti-mouse(1:1,000, Beyotime Institute of Biotechnology) at $37^{\circ} \mathrm{C}$ for $1 \mathrm{~h}$. The signals were detected with the enhanced chemiluminescence (ECL) system (Beyotime Institute of Biotechnology). The bands were scanned by Bio-Rad gel imaging system (Bio-Rad, Hercules, CA, USA) and the results were analyzed with Quantity One software. The above experiment was repeated three times.

\section{Statistical analysis}

All statistical analyses were performed using the SPSS 17.0 software (Chicago, IL, USA). Data are presented as mean \pm standard deviation (SD) and were analyzed with one-way analysis of variance (ANOVA) or Student-Newman-Keuls test. $\mathrm{P}<0.05$ was considered statistically significant.

\section{Results}

Geniposide increased cell viability of $H 9 c 2$ cells subjected to $H / R$

Cell viability was tested by CCK-8 assay at diverse time durations of $H / R(4 / 2,6 / 3$, $12 / 4,14 / 5,16 / 6,22 / 10 \mathrm{~h})$. Cell viability of H/R groups was lower than that of control group (Fig. 1A ). With $6 / 3 \mathrm{~h} \mathrm{H} / \mathrm{R}$ treatment, cell viability was reduced to $80.42 \%$ of the control

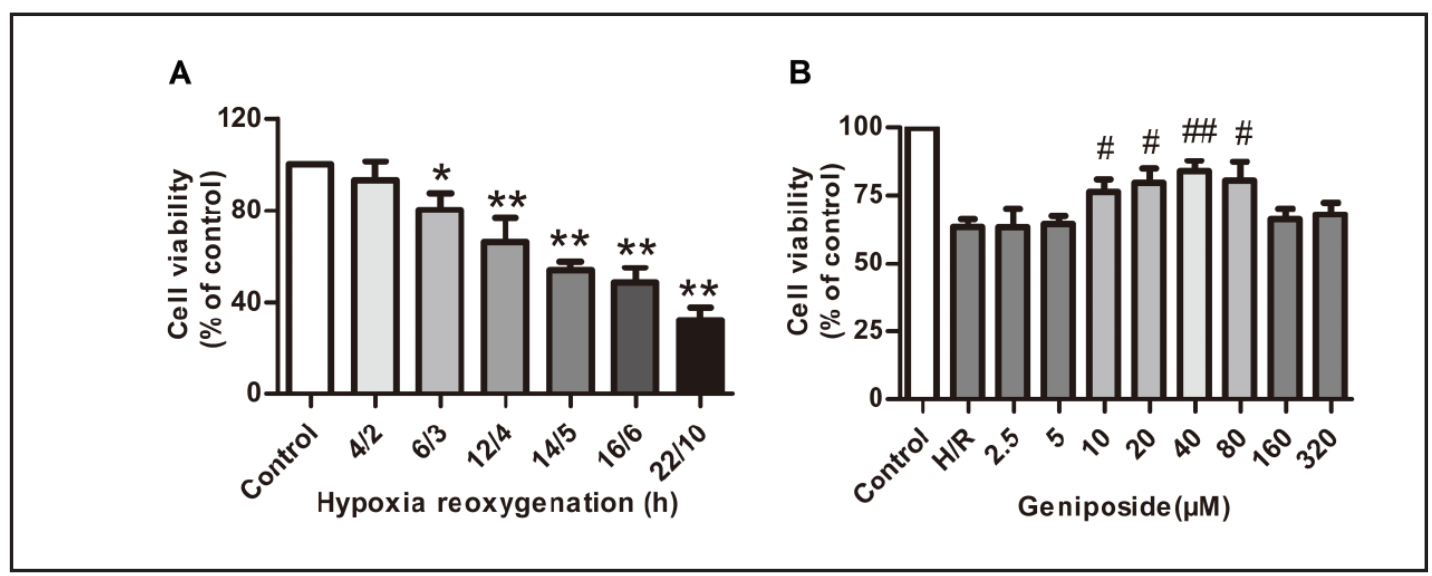

Fig. 1. Effect of hypoxia/reperfusion (H/R) and geniposide pretreatment on $H 9 c 2$ cell viability. (A) Effects of different H/R times on H9c2 cell viability. (B) Effects of gradient concentrations of geniposide pretreatment on H9c2 cell viability subjected to H/R. Data are expressed as a percentage of the control and are represented as mean \pm standard deviation (SD). $\mathrm{n}=6 .{ }^{*} \mathrm{P}<0.05,{ }^{* *} \mathrm{P}<0.01$ vs control group; $\mathrm{P}<0.05$, \#\# $\mathrm{P}<0.01$ vs $\mathrm{H} / \mathrm{R}$ group. 
Fig. 2. Effect of geniposide on lactate dehydrogenase (LDH) level in $\mathrm{H} 9 \mathrm{c} 2$ cell subjected to $\mathrm{H} / \mathrm{R}$. Values were expressed as mean $\pm \mathrm{SD} . \mathrm{n}=$ 6. ${ }^{*} \mathrm{P}<0.01$, vs control group; ${ }^{\#} \mathrm{P}<0.05$, ${ }^{\# \# ~} \mathrm{P}<$ 0.01 , vs H/R group; ${ }^{\&} \mathrm{P}<0.05$, vs $10,20 \mu \mathrm{M}$ geniposide pretreatment group.
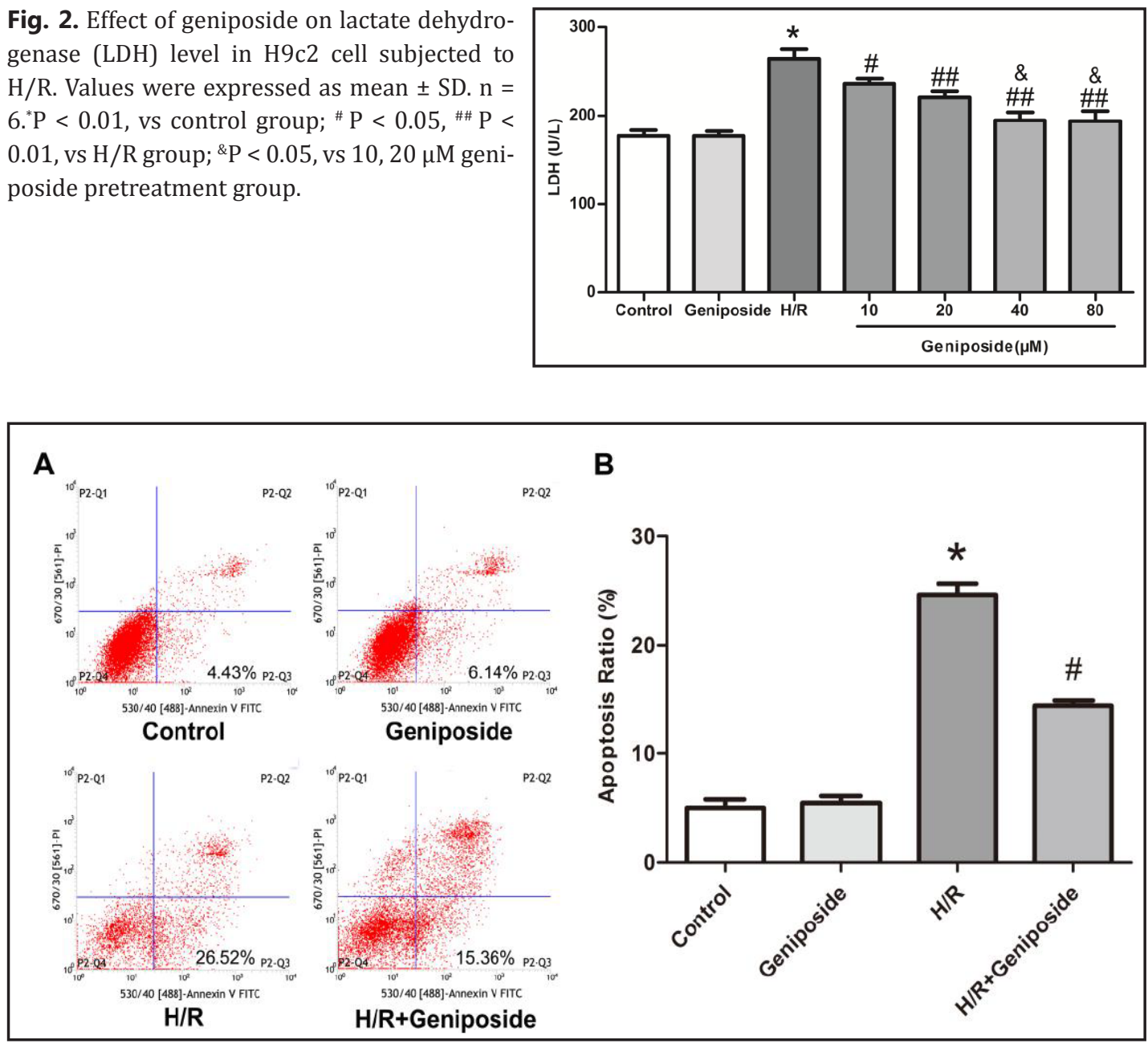

Fig. 3. Effect of geniposide pretreatment on H/R-induced apoptosis in H9c2 cells. (A) Typical images evaluated by flow cytometry. (B) The apoptosis ratio was quantified by BD FACS software. Values were expressed as mean \pm SD. $n=3 .{ }^{*} \mathrm{P}<0.01$, vs control group; $\mathrm{P}<0.01$, vs $\mathrm{H} / \mathrm{R}$ group.

group ( $\mathrm{P}<0.05$ ), while $12 / 4,14 / 5,16 / 6$, and $22 / 10 \mathrm{~h} \mathrm{H} / \mathrm{R}$ reduced cell viability to $66.30 \%$, $53.82 \%, 48.53 \%$, and $32.36 \%$ of the control group, respectively $(\mathrm{P}<0.01)$. Since the $12 / 4$ $\mathrm{h} \mathrm{H} / \mathrm{R}$ was the shortest time point when the difference in cell viability compared to control was statistically significant $(\mathrm{P}<0.01)$, this time point was selected for further study.

The effects of gradient concentrations of geniposide pretreatment on $\mathrm{H} 9 \mathrm{c} 2$ cell viability subjected to $H / R(12 / 4 \mathrm{~h})$ were observed. We found that geniposide treatment $(10,20$, $40,80 \mu \mathrm{M}$ for $30 \mathrm{~min}$ ) reversed the loss of H9c2 cells that were exposed to H/R (Fig. 1B) $(\mathrm{P}<0.05)$. Moreover, the protective effect of geniposide pretreatment on cell viability peaked at concentration $40 \mu \mathrm{M}(\mathrm{P}<0.01)$.

Geniposide decreased LDH level in $H 9 c 2$ cells subjected to $H / R$

The expression of LDH was higher in the H/R group than that in the control group $(\mathrm{P}<0.01$, Fig. 2). Geniposide pretreatment $(10,20,40,80 \mu \mathrm{M})$ remarkably reduced the level of LDH $(\mathrm{P}<0.05)$. LDH level in the $40 \mu \mathrm{M}$ and $80 \mu \mathrm{M}$ geniposide pretreatment groups were lower than that of $10 \mu \mathrm{M}$ and $20 \mu \mathrm{M}$ geniposide pretreatment groups $(\mathrm{P}<0.05$, Fig. 2$)$, but no significant difference was observed between $40 \mu \mathrm{M}$ geniposide pretreatment group and $80 \mu \mathrm{M}$ geniposide pretreatment group. Based on CCK-8 results and LDH level, $40 \mu \mathrm{M}$ of geniposide was considered the optimal concentration for further research. 


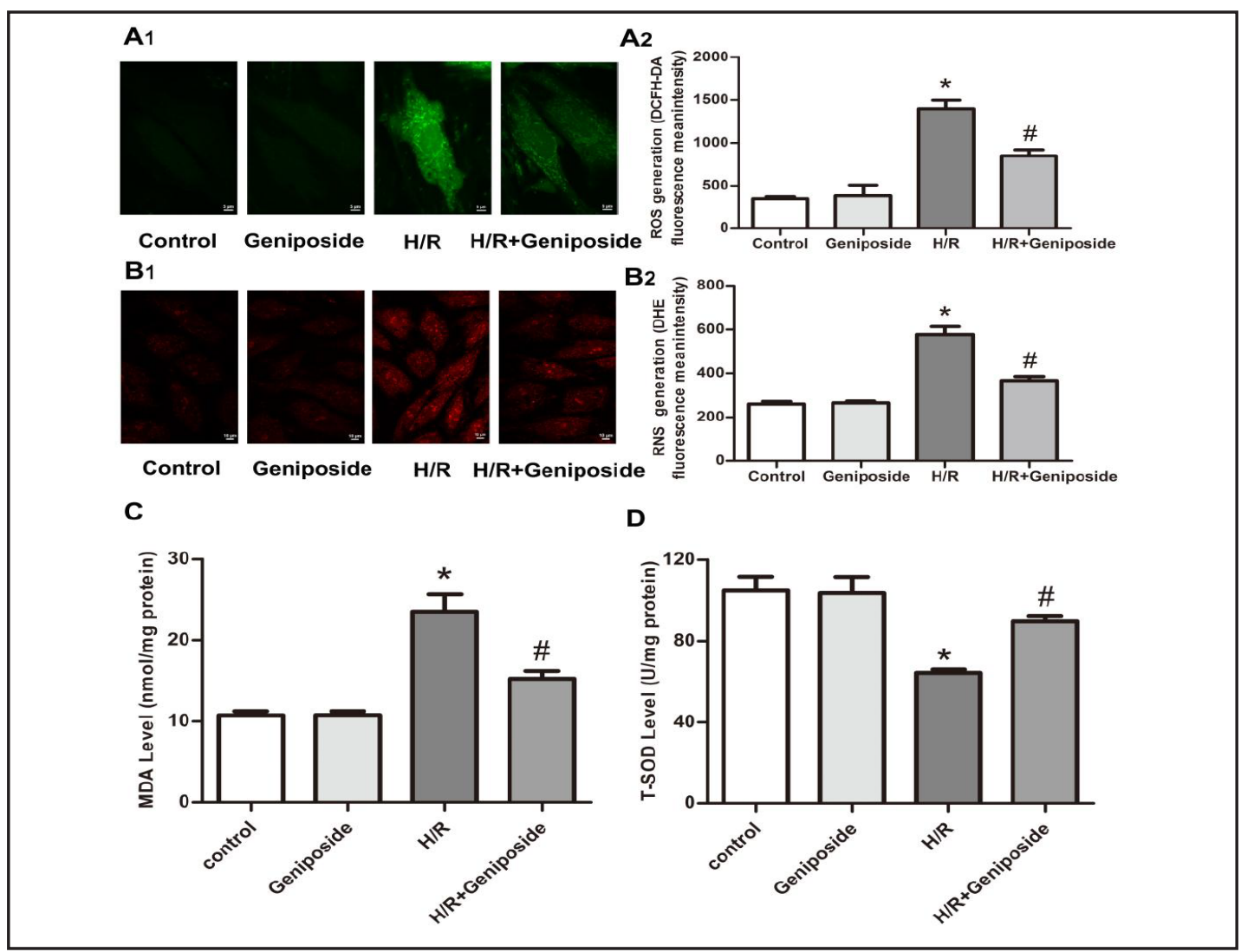

Fig. 4. Effects of geniposide pretreatment on oxidative stress product in H9c2 cells during H/R injury. ( $A_{1}$ ) The level of reactive oxygen species ROS was estimated by confocal microscopy with the probe 2', 7'-dichlorodihydrofluorescein diacetate (DCFH-DA green fluorescent image, $\times 1000)$. Scale bar: $5 \mu \mathrm{m} .\left(\mathrm{A}_{2}\right)$ Quantitative data (DCFH-DA fluorescence meanintensity) from confocal imaging were analyzed by confocal microscopy analysis software. $\left(\mathrm{B}_{1}\right)$ The level of reactive nitrogen species (RNS) was detected by confocal microscopy with dihydroethidium (DHE) probe (red fluorescent image, $\times 400)$. Scale bar:10 $\mu \mathrm{m}$. $\left(\mathrm{B}_{2}\right)$ Quantitative data (DHE fluorescence meanintensity) were analyzed by confocal microscopy analysis software. (C) Geniposide pretreatment decreased the level of malondialdehyde (MDA) during H/R. (D) Geniposide pretreatment increased the level of total superoxide dismutase (T-SOD) during H/R. Values are expressed as mean \pm SD. $n=$ 3. ${ }^{*} \mathrm{P}<0.01, \mathrm{P}<0.05$ vs control group; ${ }^{\#} \mathrm{P}<0.01, \mathrm{P}<0.05$ vs $\mathrm{H} / \mathrm{R}$ group.

\section{Geniposide attenuated H/R-induced H9c2 cell apoptosis ratio}

The apoptosis ratio of cells in the H/R group was higher than that of the control group $(\mathrm{P}<0.01)$. However, this ratio could be significantly reduced with pretreatment of geniposide ( $\mathrm{P}<0.01$, Fig. 3), indicating that geniposide could exert cardioprotective effects by inbibiting $\mathrm{H} / \mathrm{R}$-induced apoptosis of H9c2 cells.

\section{Geniposide reduced $H / R$-induced oxidative stress in $H 9 c 2$ cells induced}

The production of ROS $(\mathrm{P}<0.01)$ and RNS $(\mathrm{P}<0.05)$ was significantly increased in the $\mathrm{H} / \mathrm{R}$ group compared with that of the control group. Nonetheless, geniposide pretreatment significantly decreased the production of ROS $(\mathrm{P}<0.01)$ and RNS $(\mathrm{P}<0.05)$ induced by H/R (Fig. 4A and B).

Intracellular levels of T-SOD and MDA were measured to confirm further the antioxidative ability of geniposide. In the H/R group, the production of MDA was increased dramatically in comparison to that of control group, whereas, T-SOD level was extremely decreased $(\mathrm{P}<0.01$, Fig. 4C and D). In contrast, While geniposide pretreatment significantly weakened this increase of MDA $(\mathrm{P}<0.05)$ and decrease of T-SOD $(\mathrm{P}<0.01)$.

\section{KARGER}




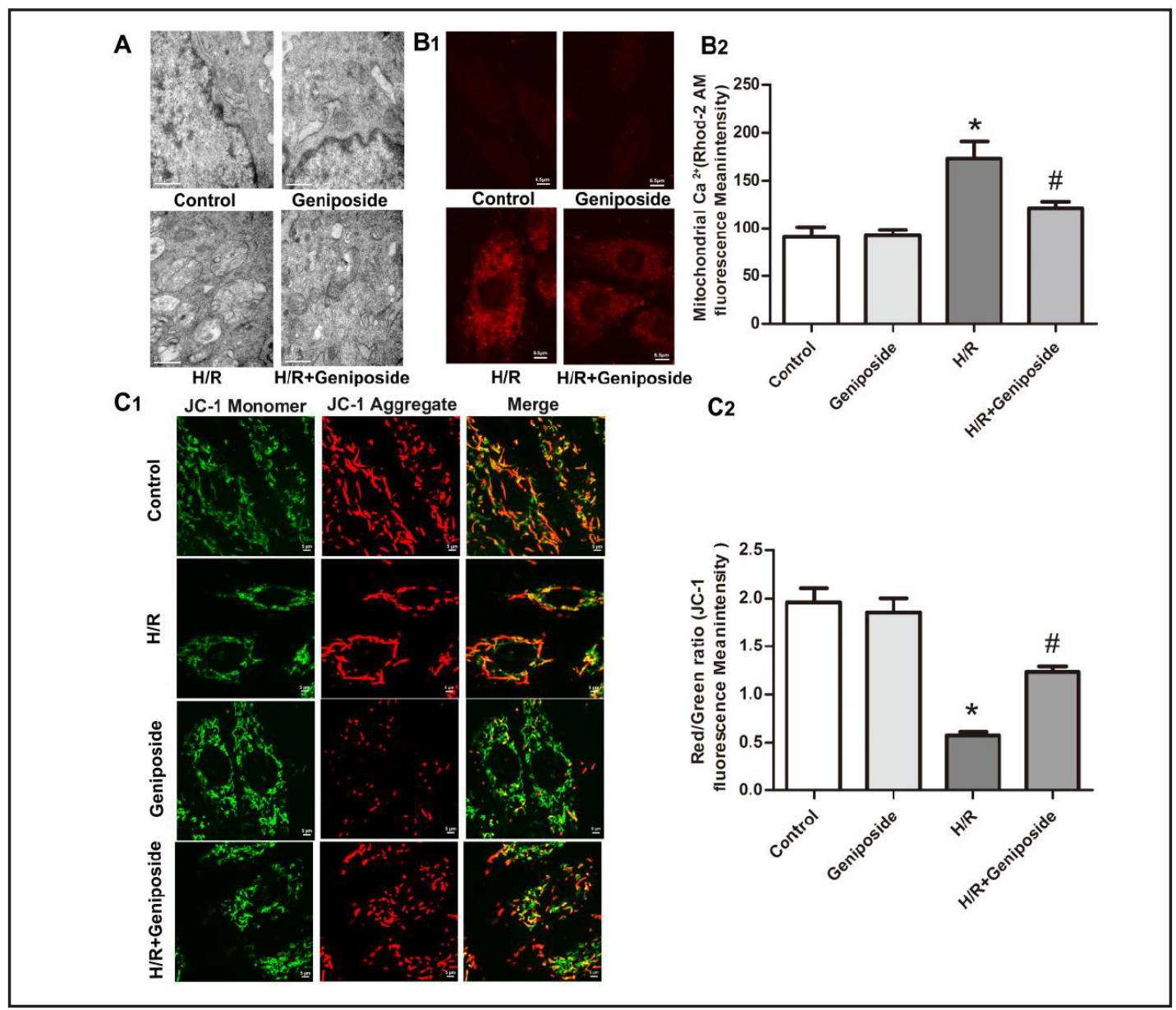

Fig. 5. The effect of geniposide pretreatment on mitochondrial morphological changes, [Ca2+]m and $\Delta \Psi \mathrm{m}$ in H9c2 cells during H/R. (A) Geniposide pretreatment improved the mitochondrial morphological changes in $\mathrm{H} 9 \mathrm{c} 2$ cells subjected to H/R. $(\times 4000)$ Scale bar: $0.5 \mu \mathrm{m} .\left(\mathrm{B}_{1}\right)[\mathrm{Ca} 2+] \mathrm{m}$ was examined by confocal microscopy with Rhod 2 AM probe (red fluorescent image, $\times 800$ ). Scale bar: $5 \mu \mathrm{m}$. $\left(\mathrm{B}_{2}\right)$ Quantitative data (Rhod $2 \mathrm{AM}$ fluorescence meanintensity) were analyzed by confocal microscopy analysis software. $\left(\mathrm{C}_{1}\right)$ Depolarization of $\Delta \Psi \mathrm{m}$ was measured by confocal image using JC-1 probe. Red and green fluorescence images represented polarized and depolarized mitochondria, respectively, while the ratio of red to green represented the depolarization ratio of $\Delta \Psi \mathrm{m}(\times 800)$. Scale bar: $5 \mu \mathrm{m} .\left(\mathrm{C}_{2}\right)$ Quantitative data (JC-1 fluorescence meanintensity) were analyzed by confocal microscopy analysis software. Values are expressed as mean $\pm \mathrm{SD}$. $\mathrm{n}=3$. ${ }^{*} \mathrm{P}<0.05$, vs control group. ${ }^{\mathrm{P}}<0.05$, vs $\mathrm{H} / \mathrm{R}$ group.

Geniposide improved mitochondrial morphological changes and reduced mitochondrial calcium overload and the depolarization of mitochondrial membrane potential in $\mathrm{H} 9 \mathrm{c} 2$ cells subjected to $H / R$

In the $H / R$ group, changes in mitochondrial morphology, such as swelling, disorganization, and reduction or vanishing of the crista, were increased compared to the control group. Pretreatmen with $40 \mu \mathrm{M}$ geniposide, however, improved these mitochondrial morphological changes in H9c2 cells induced by H/R (Fig. 5A). Mitochondrial calcium $\left(\left[\mathrm{Ca}^{2+}\right]_{\mathrm{m}}\right)$ of the $\mathrm{H} / \mathrm{R}$ group was distinctly increased compared with that of control group $(\mathrm{P}<0.05)$, while this increase was reversed with $40 \mu \mathrm{M}$ geniposide pretreatment $(\mathrm{P}<0.05)$ (Fig. 5B).

Polarized (red) and depolarized (green) mitochondria were detected by confocal laser scanning microscope using the JC-1 probe. The depolarization ratio of $\Delta \Psi \mathrm{m}$ was represented by the fluorescence ratio of red to green. Red fluorescence decreased while green fluorescence 


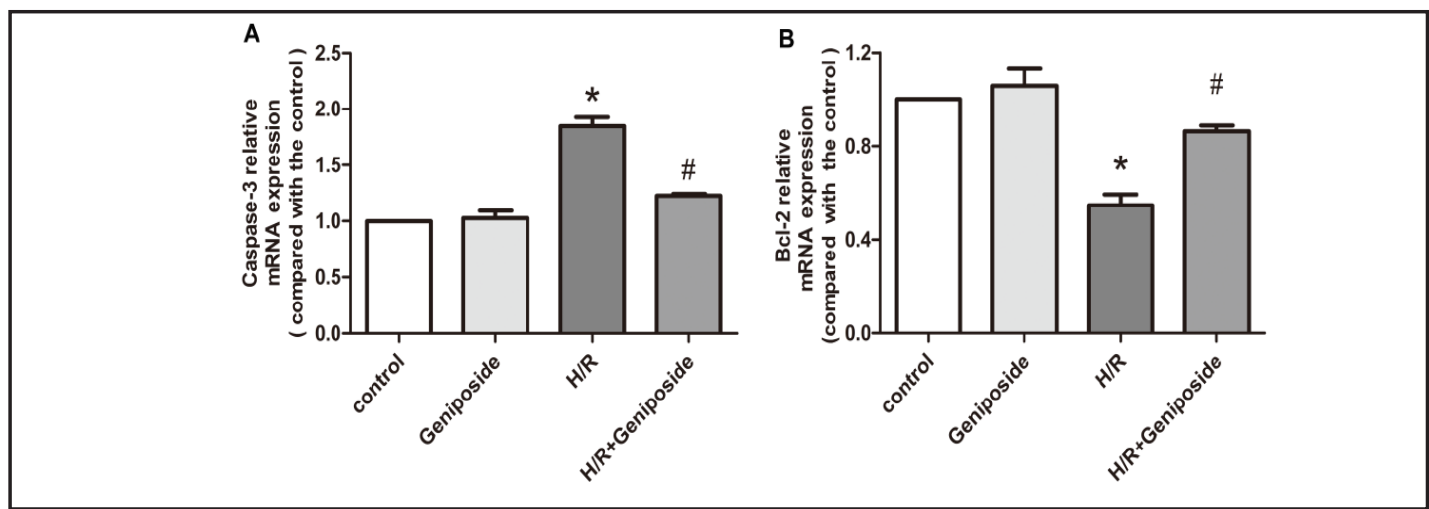

Fig. 6. Effect of geniposide pretreatment on caspase-3 and Bcl-2 mRNA expression in H9c2 cells during H/R. (A) Geniposide downregulated caspase-3 mRNA expression. (B) Geniposide upregulated Bcl-2 mRNA expression. Values were expressed as mean $\pm \mathrm{SD} . \mathrm{n}=3$. ${ }^{*} \mathrm{P}<0.05$, vs control group; ${ }^{\mathrm{P}}<0.05$, vs $\mathrm{H} / \mathrm{R}$ group.

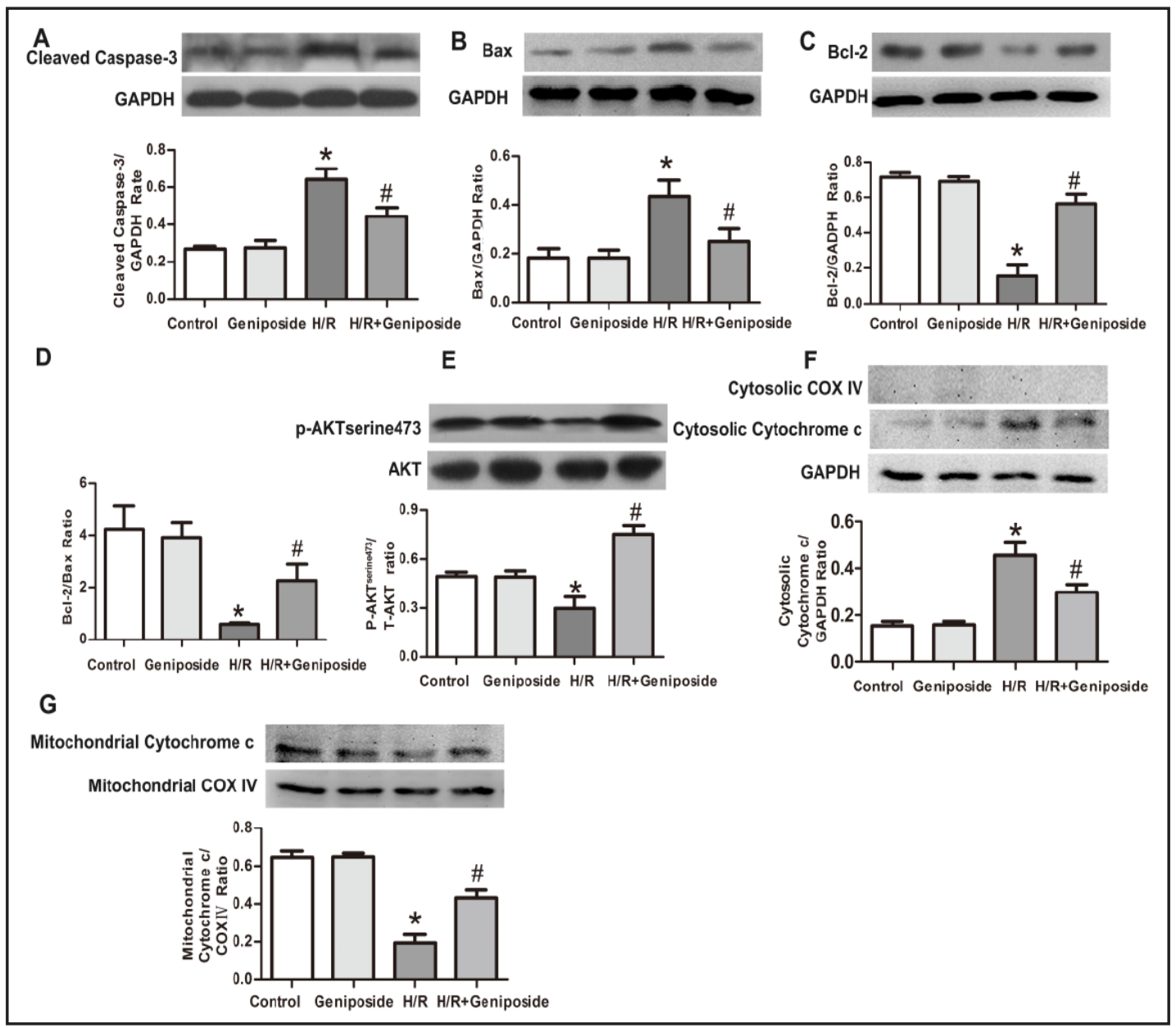

Fig. 7. Effects of geniposide pretreatment on cleaved caspase-3, cytochrome-c, Bax, Bcl-2, and p-AKTserine473 expressions in H/R-treated H9c2 cells. (A) Representative bands of cleaved caspase-3 and quantitative analysis results. (B) Representative bands of Bax and quantitative analysis results.(C) Representative bands of Bcl-2 and quantitative analysis results. (D) Quantitative analysis results of Bcl-2/Bax Ratios. (E) Representative bands of p-AKTserine473 and quantitative analysis results of p-AKTserine473/T-AKT ratio. (F) Representative bands of cytosol cytochrome-c and quantitative analysis results. (G) Representative bands of mitochondrial cytochrome-c and quantitative analysis results.Values are expressed as mean \pm SD. ${ }^{*} \mathrm{P}<0.01, \mathrm{P}<0.05$ vs Control group; $\mathrm{P}<0.05$ vs H/R group. 


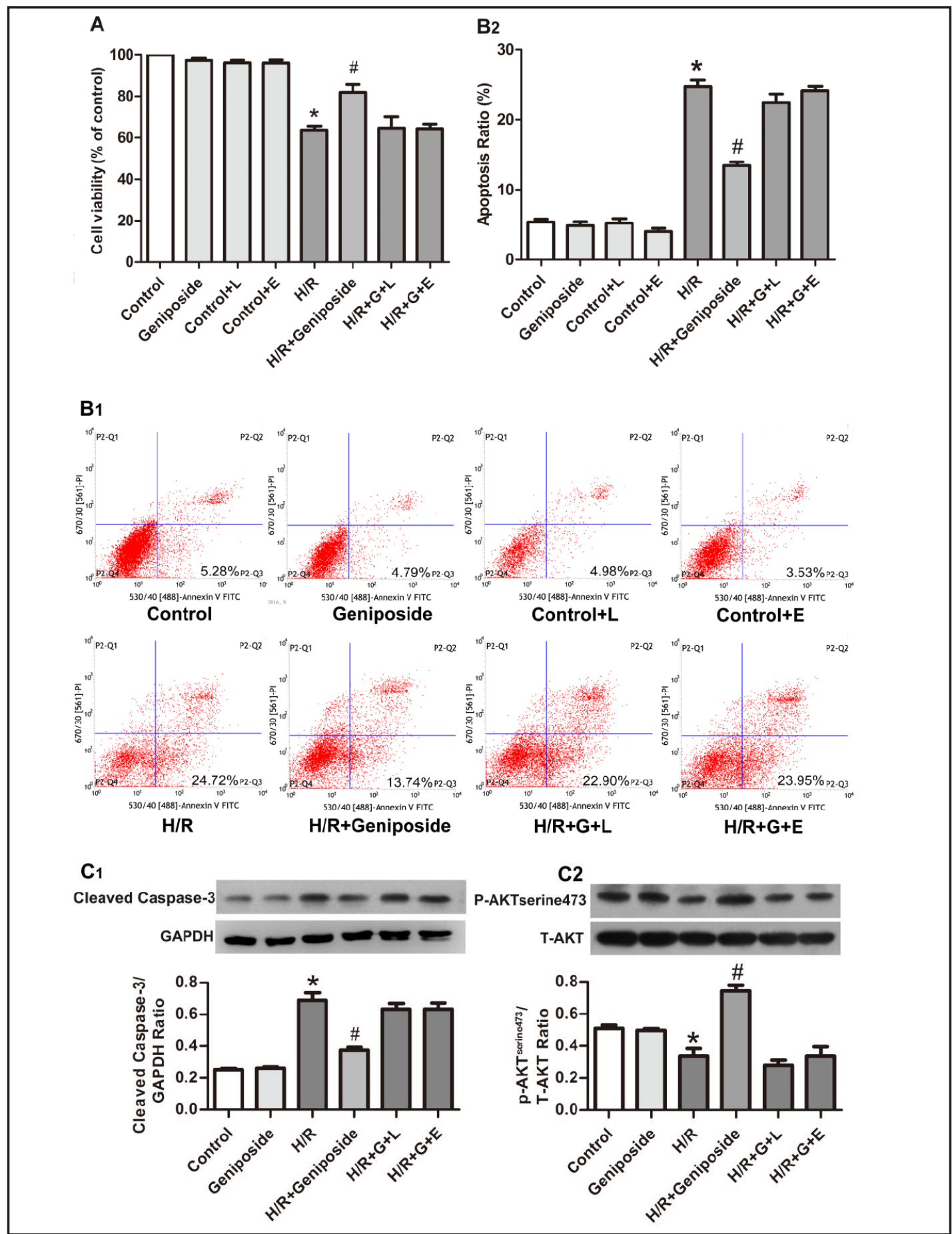

Fig. 8. Exendin (9-39) (200 nM) and LY294002 (15 $\mu \mathrm{M})$ inhibited the protective effects of geniposide on H9c2 cells during H/R. (A) The effect of geniposide, Exendin (9-39) and LY294002 on H9c2 cells during H/R. $\left(B_{1}\right)$ Representative apoptosis images of flow cytometry. $\left(B_{2}\right)$ The apoptosis ratios were quantified by BD FACS software. $\left(C_{1}\right)$ Representative bands of cleaved caspase-3 and quantitative analysis results. $\left(C_{2}\right)$ Representative bands of p-AKTserine 473 and quantitative analysis results of p-AKTserine473/T-AKT ratio. ${ }^{*} \mathrm{P}<0.01, \mathrm{P}<0.05$ vs. control group; ${ }^{\#} \mathrm{P}<0.01, P<0.05$ vs. H/R group. Values are expressed as mean $\pm \mathrm{SD} . \mathrm{n}=3$.

remarkably increased in the $H / R$ group compared with that of the control group $(\mathrm{P}<0.05$, Fig. 5C), showing that $H / R$ downregulated the red to green ratio. This ratio in the geniposide pretreatment group was increased compared to that of the H/R group $(\mathrm{P}<0.05)$. 


\section{Cellular Physiology Cell Physiol Biochem 2016;39:407-421 \begin{tabular}{c|c|c|} 
DOI: 10.1159/000445634 & $\begin{array}{l}\text { O 2016 The Author(s). Published by S. Karger AG, Basel } \\
\text { wwww.karger.com/cpb }\end{array}$
\end{tabular} \\ Jiang et al.: Geniposide Prevents Hyposia/ Reoxygenation-Induced Apoptosis In H9c2 cells}

Geniposide downregulated caspase-3 mRNA expression and upregulated Bcl-2 mRNA expression in $H 9 c 2$ cells induced by $H / R$

The RT-PCR results revealed that caspase- 3 mRNA expression increased and Bcl-2 mRNA expression decreased significantly after $\mathrm{H} / \mathrm{R}(\mathrm{P}<0.05)$, while this trend was attenuated by geniposide pretreatment $(\mathrm{P}<0.05$, Fig. 6).

Geniposide inhibited cleaved caspase-3, Cytochrome-c, Bax protein expression and augmented $B c l-2$ and $p$-AKT ${ }^{\text {serine } 473}$ levels

As shown in Fig. 7, protein expression in the H/R group of cleaved caspase-3 (P $<0.01$, Fig. 7A), cytochrome-c $(\mathrm{P}<0.05$, Fig. 7F and $\mathrm{G})$ and $\mathrm{Bax}(\mathrm{P}<0.05$, Fig. 7B) was increased while the expression of Bcl-2 $\left(\mathrm{P}<0.01\right.$, Fig. 7C) and p-AKT ${ }^{\text {serine } 473}(\mathrm{P}<0.01$, Fig. 7E $)$ was decreased compared to that of the control group. In comparison, pretreatment with geniposide remarkably decreased protein expression of caspase-3, cytochrome-c, and Bax and increased protein expression of Bcl-2 and p-AKT ${ }^{\text {serine } 473}$, thus enhancing the Bcl-2/Bax ratio $(\mathrm{P}<0.05$, Fig. 7D).

In oder to investigate the translocation of cytochrome $\mathrm{c}$ from mitochondria into the cytosol, we analyzed the expression level of cytochrome $\mathrm{c}$ in the cytosolic and mitochodrial fractions by western blot. As shown in Fig. 7F and G, the level of mitochondrial cytochrome $\mathrm{c}$ decreased and the level of cytosolic cytochrome $\mathrm{c}$ increased in H/R group compared with those of the control group $(\mathrm{P}<0.05)$. Geniposide treatment, however, reduced the level of cytochrome $\mathrm{c}$ released into cytosol $(\mathrm{P}<0.05)$. We did not detect COXIV (a mitochondrial marker) in the cytosol, indicating that the cytosolic fraction was not contaminated with mitochondrial proteins.

Cardioprotection of geniposide involved activation of GLP-1R and the PI3K/AKT signaling pathway

To investigate further the antiapoptotic mechanism of geniposide on H9c2 cells induced by $\mathrm{H} / \mathrm{R}$, we determined the effect of GLP-1R antagonist exendin (9-39) and the PI3K inhibitor LY294002 on geniposide cardioprotection. As shown in Fig. 8A, the cell viability of the H/R group was decreased compared with that of the control group $(\mathrm{P}<0.01)$, while, pretreatment with geniposide increased cell viability $(\mathrm{P}<0.05)$. This effect of geniposide was inhibited by LY294002 and exendin (9-39). There was no significant difference in cell viability among the control + E, control + L, Geniposide, and control groups. The apoptosis raito of the H/R group was higher than that of contol group $(\mathrm{P}<0.01)$, which geniposide pretreatment reduced $(\mathrm{P}$ $<0.01$ ). Exendin (9-39) and LY294002, however, blocked the effects of geniposide (Fig. 8B). The differences in the apoptosis ratios of control $+\mathrm{E}$, control $+\mathrm{L}$, Geniposide, and control groups were not significant. Preincubation with geniposide decreased the protein level of cleaved caspase-3 $(\mathrm{P}<0.05)$ and an increased the protein level of $\mathrm{P}-\mathrm{AKT}^{\text {serine473 }}(\mathrm{P}<0.05)$, which were supressed by LY294002 and exendin (9-39) (Fig. 8C). Taken together, these findings suggested that the protection of geniposide might be, at least in part, associated with activing the GLP-1R and PI3K/AKT signaling pathway.

\section{Discussion}

Our findings revealed that geniposide, a promising cardioprotective natural extractive, could inhibit apoptosis in $\mathrm{H} 9 \mathrm{c} 2$ cells apoptosis by improving mitochondrial dysfunction, as demonstrated by improved mitochondrial morphological changes, attenuating mitochondrial oxidative stress, reduced mitochondrial calcium overload, and preservation of mitochondrial membrane potential. This study is the first to demonstrate that anti-apoptotic effects of geniposide regarding mitochondrial function involve GLP-1R, and the PI3K/AKT signaling pathway in H9c2 cells in response to the H/R injury.

Cell viability is an important index to determine cell survival. LDH, one marker of cardiomyocyte injury, leaks out into the blood-stream when the cell membrane becomes 
permeable or ruptures [26]. In the present study, geniposide pretreatment mitigated increases in LDH level and increased $H 9 c 2$ cell viability during $H / R$, suggesting its protective effects on cardiomyocytes against H/R-caused damage.

Cardiomyocyte apoptosis induced by I/R is an essential process in the progression of heart failure. Mitochondria play a crucial role in cardiomyocyte apoptosis under hypoxic conditions $[3,4]$. This study showed that $H / R$ treatment caused mitochondrial dysfunction and cardiomyocyte apoptosis, whereas, pretreatment with geniposide improved mitochondrial dysfunction and attenuated mitochondria-dependent cell apoptosis.

In addition to their significant role in cell apoptosis, mitochondria are also the primary sources of oxidative stress during H/R $[3,10]$. ROS and RNS are products of mitochondrial oxidative stress, and production of ROS is a vital step in the mitochondria-dependent apoptosis pathway [3, 4, 27]. Physiological levels of ROS/RNS in normal oxidative metabolism play a key homeostatic role in balancing disposal rates of oxidative pressure and enzyme systems in cell proliferation and survival [27-29]. As levels of SOD, glutathione, and catalase are less in the cardiac system, excessive production of ROS/RNS triggers oxidative stress and aggravates ischemia-induced cardiomyocyte damage [27, 30], further accelerating cardiomyocyte apoptosis and loss [31,32]. Treatment with antioxidant agents or upregulation of endogenous antioxidant enzymes could prevent excessive ROS-caused injury $[4,33,34]$. Here, we showed that the generation of ROS and RNS were obviously augmented in the $\mathrm{H} / \mathrm{R}$ group compared to that in the control group and that, this effect was notably reduced by geniposide pretreatment. Moreover, the oxidative product MDA was clearly decreased and the antioxidant enzyme T-SOD was remarkably increased in the H/R + geniposide group compared with that of H/R group. Therefore, we have shown for the first time that geniposide pretreatment inhibited ROS/RNS and, MDA synthesis and elevated T-SOD levels in H9c2 cells during $\mathrm{H} / \mathrm{R}$, resulting in attenuation of mitochondria oxidative stress as an analogous antioxidant.

Mitochondrial oxidative stress triggered by excessive ROS accelerates mitochondria malfunction, decreases energy supply of mitochondria, and destroys calcium homeostasis, leading to mitochondrial calcium overload. This combination of excessive ROS and mitochondrial calcium overload assault mitochondria membranes, nucleic acids, proteins, and lipids, resulting in nuclear DNA degradation. In addition, they open mPTP, increase the depolarization ratio of $\Delta \Psi \mathrm{m}$, rupture the mitochondria outer membrane, promote release of cytochrome-c, and activate cytochrome-c-mediated caspase family, finally leading to cell apoptosis and death [35, 36]. Importantly, consistent with the result of ROS, geniposide pretreatment remarkably decreased $[\mathrm{Ca} 2+] \mathrm{m}$ and the depolarization ratio of $\Delta \Psi \mathrm{m}$ and improved mitochondrial morphological changes. Moreover, Lv et al. found that geniposide might attenuate mitochondrial oxidative stress-induced memory deficits by suppressing ROS generation and the augmenting $\triangle \Psi \mathrm{m}$ in APP/PS1 mice [25]. In this study, we found that geniposide pretreatment inhibited H/R-caused apoptosis in H9c2 cells by improving mitochondrial dysfunction.

A crucial function of Bcl-2 is to regulate the activation of mitochondrial outer membrane permeability (MOMP) and MPTP, which are the central switch of mitochondria-dependent apoptosis [8]. Bcl-2 inhibits MOMP, while Bax protein activates MOMP. Moreover, apoptosis associated $\mathrm{Bcl}-2$ activation regulates two-way cross-talk between the mitochondria and endoplasmic reticulum (ER) which has an essential role in Ca2+ stores [37]. Bcl-2, an anti-apoptotic protein, facilitates $\mathrm{Ca}^{2+}$ leakage, allows ER $\mathrm{Ca}^{2+}$ unloading, and decreases mitochondrial $\mathrm{Ca}^{2+}$ overload. Bax, a pro-apoptotic protein, blocks $\mathrm{Ca}^{2+}$ leakage, increases $\mathrm{ER} \mathrm{Ca}^{2+}$ stores, augments ER $\mathrm{Ca}^{2+}$ release, increases mitochondria $\mathrm{Ca}^{2+}$ uptake, and ultimate accelerates mitochondria $\mathrm{Ca}^{2+}$ overload $[8,38]$. However, in the present study, geniposide pretreatment increased $\mathrm{Bcl}-2$ protein level and attenuated Bax protein in H/R-treated $\mathrm{H} 9 \mathrm{c} 2$ cells, and preserved the ratio of Bcl-2/Bax. In addition, Bcl-2 mRNA expression was enhanced in the $\mathrm{H} / \mathrm{R}+$ geniposide group. The decrease of Bcl-2/Bax ratio, mitochondria calcium overload, and opening of mPTP further collapsed mitochondria membrane potential and ruptured the outer membrane of mitochondria, finally releasing pro-apoptotic

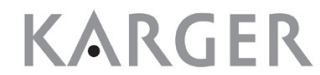




\section{Cellular Physiology Cell Physiol Biochem 2016;39:407-421 \\ \begin{tabular}{c|c|c|} 
DOI: 10.1159/000445634 & $\begin{array}{l}\text { O 2016 The Author(s). Published by S. Karger AG, Basel } \\
\text { www.karger.com/cpb }\end{array}$
\end{tabular} \\ Jiang et al.: Geniposide Prevents Hyposia/ Reoxygenation-Induced Apoptosis In H9c2 \\ cells}

molecules into the cytoplasm [35]. Surprisingly, we found that geniposide not only alleviated $\Delta \Psi \mathrm{m}$ depolarization and mitochondria $\mathrm{Ca} 2+$ overload, but it also inhibited the release of cytochrome-c from mitochondria. Subsequently, cytochrome-c release into the cytosol activated the procaspase-9, thereby magnifying downstream caspases cascades such as caspase-3, and leading to nuclear DNA degradation and formation of apoptotic bodies $[9,39]$. In our study, geniposide pretreatment remarkably reduced both the protein and mRNA expressions of caspase-3 and Bcl-2. Taken together, these results suggested that geniposide pretreatment protected H9c2 cells against H/R-caused injury through Bcl-2/ Bax/mitochondria apoptotic pathways.

GLP-1, a gut hormone, and GLP-1 analogs have beneficial effects on cardiovascular system by inhibiting cardiomyocyte apoptosis during I/R [23, 40-43]. It has been reported that geniposide, as a novel GLP-1R agonist, exerts different protective effects by activating GLP$1 \mathrm{R}$ in various tissues [15-19]. GLP-1R is expressed in various tissues and organs, including the pancreas, gastrointestinal tract, nervous system, blood vessels, and heart [44, 45].. Activated GLP-1R mediates the cAMP/ protein kinase A (PKA)/ cAMP-responsive element binding protein (CREB) pathway, resulting in the activation of phosphatidylinositol-3 kinase (PI3K), AKT-protein kinase B (AKT/PKB), and extracellular regulated kinase (ERK1/2) signaling pathway $[32,46]$. Accumulating evidence has revealed that AKT activation plays a crucial role in the cardioprotective effect after ischemia-reperfusion injury. Activation of the anti-apoptotic signaling pathway PI3K/AKT could regulate Bcl-2, inhibit caspase cascade activation and reduce death gene expression [32]. In our study, the improvement of cell viability and attenuation of cell apoptosis ratio by geniposide pretreatment during H/R were blocked by exendin (9-39) and LY294002 to some extent. Furthermore, the effects of geniposide pretreatment on decreasing cleaved-caspase-3 protein expression and augmenting p-AKT ${ }^{\text {serine473 }}$ /Total-AKT ratio during H/R were also reversed by exendin (9-39) and LY294002. Our experimental results indicated that the underlying mechanisms of the cardioprotective effects of geniposide pretreatment during H/R involved the activation GLP$1 \mathrm{R}$ and downstream of PI3K/AKT signaling pathways.

Based on the above results, we concluded that geniposide pretreatment could decrease cardiomyocyte apoptosis during H/R injury. The underlying mechanisms might be the activation of GLP-1R and downstream of PI3K/AKT signaling pathways. Therefore, geniposide may useful as novel therapeutic drug for ischemic heart disease.

\section{Acknowledgments}

This work was supported by the Traditional Chinese Medicine of Chongqing Municipal Health Bureau (Grant No. ZY20132124), the Science and Technology Plan Projects of Chongqing (Grant No. 20140111), the National Natural Science Fund (Grant No.85170212), the Natural Science Foundation Project of CQ CSTC (Grant NO. cstc2011jjA10008) and the National Key Clinical Specialties Construction Program of China (Grant No.2011-170). All studies were performed at Chongqing Key Laboratory of Ophthalmology.

\section{Disclosure Statement}

We confirm that there are no known conflicts of interest associated with this publication and there has been no significant financial support for this work that could have influenced its outcome.

\section{References}

1 Sun L, Fan H, Yang L, Shi L, Liu Y: Tyrosol prevents ischemia/reperfusion-induced cardiac injury in H9c2 cells: involvement of ROS, Hsp70, JNK and ERK, and apoptosis. Molecules 2015;20:3758-3775. 
Jiang et al.: Geniposide Prevents Hyposia/ Reoxygenation-Induced Apoptosis In H9c2 cells

2 Zhu T, Yao Q, Hu X, Chen C, Yao H, Chao J: The Role of MCPIP1 in Ischemia/Reperfusion Injury-Induced HUVEC Migration and Apoptosis. Cell Physiol Biochem 2015;37:577-591.

3 Chang G, Zhang D, Liu J, Zhang P, Ye L, Lu K, Duan Q Zheng A, Qin S: Exenatide protects against hypoxia/ reoxygenation-induced apoptosis by improving mitochondrial function in H9c2 cells. Exp Biol Med 2014;239:414-422.

4 Kuo CY, Chiu YC, Lee AY, Hwang TL: Mitochondrial Lon protease controls ROS-dependent apoptosis in cardiomyocyte under hypoxia. Mitochondrion 2015;23:7-16.

5 Palojoki E, Saraste A, Eriksson A, Pulkki K, Kallajoki M, Voipio-Pulkki LM, Tikkanen I: Cardiomyocyte apoptosis and ventricular remodeling after myocardial infarction in rats. Am J Physiol Heart Circ Physiol 2001;280:H2726-2731.

6 Li D, Liu M, Tao TQ, Song DD, Liu XH, Shi DZ: Panax quinquefolium saponin attenuates cardiomyocyte apoptosis and opening of the mitochondrial permeability transition pore in a rat model of ischemia/ reperfusion. Cell Physiol Biochem 2014;34:1413-1426.

7 Lee Y, Gustafsson AB: Role of apoptosis in cardiovascular disease. Apoptosis 2009;14:536-548.

8 Webster KA: Mitochondrial membrane permeabilization and cell death during myocardial infarction: roles of calcium and reactive oxygen species. Future Cardiol 2012;8:863-884.

9 Shan H, Yan R, Diao J, Lin L, Wang S, Zhang M, Zhang R, Wei J: Involvement of caspases and their upstream regulators in myocardial apoptosis in a rat model of selenium deficiency-induced dilated cardiomyopathy. J Trace Elem Med Biol 2015;31:85-91.

10 Poyton RO, Ball KA, Castello PR: Mitochondrial generation of free radicals and hypoxic signaling. Trends Endocrinol Metab 2009;20:332-340.

11 Tao L, Bei Y, Lin S, Zhang H, Zhou Y, Jiang J, Chen P, Shen S, Xiao J, Li X: Exercise Training Protects Against Acute Myocardial Infarction via Improving Myocardial Energy Metabolism and Mitochondrial Biogenesis. Cell Physiol Biochem 2015;37:162-175.

12 Penna C, Perrelli MG, Pagliaro P: Mitochondrial pathways, permeability transition pore, and redox signaling in cardioprotection: therapeutic implications. Antioxid Redox Signal 2013;18:556-599.

13 Zhang P, Lu Y, Yu D, Zhang D, Hu W: TRAP1 Provides Protection Against Myocardial Ischemia-Reperfusion Injury by Ameliorating Mitochondrial Dysfunction. Cell Physiol Biochem 2015;36:2072-2082.

14 Littlejohns B, Lin H, Angelini GD, Halestrap AP, Suleiman MS: Switching back to normal diet following highfat diet feeding reduces cardiac vulnerability to ischaemia and reperfusion injury. Cell Physiol Biochem 2014;34:1090-1100.

15 Gong N, Fan H, Ma AN, Xiao Q, Wang YX: Geniposide and its iridoid analogs exhibit antinociception by acting at the spinal GLP-1 receptors. Neuropharmacology 2014;84:31-45.

16 Yao DD, Yang L, Wang Y, Liu C, Wei YJ, Jia XB, Yin W, Shu L: Geniposide promotes beta-cell regeneration and survival through regulating beta-catenin/TCF7L2 pathway. Cell Death Dis 2015;6:e1746.

17 Liu J, Yin F, Xiao H, Guo L, Gao X: Glucagon-like peptide 1 receptor plays an essential role in geniposide attenuating lipotoxicity-induced beta-cell apoptosis. Toxicol In Vitro 2012;26:1093-1097.

18 Guo LX, Xia ZN, Gao X, Yin F, Liu JH: Glucagon-like peptide 1 receptor plays a critical role in geniposideregulated insulin secretion in INS-1 cells. Acta Pharmacol Sin 2012;33:237-241.

19 Liu J, Yin F, Zheng X, Jing J, Hu Y: Geniposide, a novel agonist for GLP-1 receptor, prevents PC12 cells from oxidative damage via MAP kinase pathway. Neurochem Int 2007;51:361-369.

20 Shi L, Ji Y, Jiang X, Zhou L, Xu Y, Li Y, Jiang W, Meng P, Liu X: Liraglutide attenuates high glucose-induced abnormal cell migration, proliferation, and apoptosis of vascular smooth muscle cells by activating the GLP-1 receptor, and inhibiting ERK1/2 and PI3K/Akt signaling pathways. Cardiovasc Diabetol 2015;14:18.

21 Zhang H, Meng J, Li X, Zhou S, Qu D, Wang N, Jia M, Ma X, Luo X: Pro-GLP-1, a Pro-drug of GLP-1, is neuroprotective in cerebral ischemia. Eur J Pharm Sci 2015;70:82-91.

22 Favaro E, Granata R, Miceli I, Baragli A, Settanni F, Cavallo Perin P, Ghigo E, Camussi G, Zanone MM: The ghrelin gene products and exendin-4 promote survival of human pancreatic islet endothelial cells in hyperglycaemic conditions, through phosphoinositide 3-kinase/Akt, extracellular signal-related kinase (ERK)1/2 and cAMP/protein kinase A (PKA) signalling pathways. Diabetologia 2012;55:1058-1070.

23 Bhashyam S, Fields AV, Patterson B, Testani JM, Chen L, Shen YT, Shannon RP: Glucagon-like peptide-1 increases myocardial glucose uptake via p38alpha MAP kinase-mediated, nitric oxide-dependent mechanisms in conscious dogs with dilated cardiomyopathy. Circ Heart Fail 2010;3:512-521. 
Jiang et al.: Geniposide Prevents Hyposia/ Reoxygenation-Induced Apoptosis In H9c2 cells

24 Guo LX, Liu JH, Xia ZN. Geniposide inhibits CoCl2-induced PC12 cells death via the mitochondrial pathway. Chin Med J 2009;122:2886-2892.

25 Lv C, Liu X, Liu H, Chen T, Zhang W: Geniposide attenuates mitochondrial dysfunction and memory deficits in APP/PS1 transgenic mice. Curr Alzheimer Res 2014;11:580-587.

26 Cai Y, Hu X, Yi B, Zhang T, Wen Z: Glucagon-like peptide-1 receptor agonist protects against hyperglycemiainduced cardiocytes injury by inhibiting high mobility group box 1 expression. Mol Biol Rep 2012;39:10705-10711.

27 Navarro-Yepes J, Burns M, Anandhan A, Khalimonchuk O, del Razo LM, Quintanilla-Vega B, Pappa A, Panayiotidis MI, Franco R: Oxidative stress, redox signaling, and autophagy: cell death versus survival. Antioxid Redox Signal 2014;21:66-85.

28 Finkel T: Signal transduction by reactive oxygen species. J Cell Biol 2011;194:7-15.

29 Halliwell B: Reactive oxygen species and the central nervous system. J Neurochem 1992;59:1609-1623.

30 Chen HM, Hsu JH, Liou SF, Chen TJ, Chen LY, Chiu CC, Yeh JL: Baicalein, an active component of Scutellaria baicalensis Georgi, prevents lysophosphatidylcholine-induced cardiac injury by reducing reactive oxygen species production, calcium overload and apoptosis via MAPK pathways. BMC Complement Altern Med 2014;14:233.

31 Zhao ZQ: Oxidative stress-elicited myocardial apoptosis during reperfusion. Curr Opin Pharmacol 2004;4:159-165.

32 Chang G, Zhang D, Yu H, Zhang P, Wang Y, Zheng A, Qin S: Cardioprotective effects of exenatide against oxidative stress-induced injury. Int J Mol Med 2013;32:1011-1020.

33 Loesser KE, Kukreja RC, Kazziha SY, Jesse RL, Hess ML: Oxidative damage to the myocardium: a fundamental mechanism of myocardial injury. Cardioscience 1991;2:199-216.

34 Suzuki K, Murtuza B, Sammut IA, Latif N, Jayakumar J, Smolenski RT, Kaneda Y, Sawa Y, Matsuda H, Yacoub $\mathrm{MH}$ : Heat shock protein 72 enhances manganese superoxide dismutase activity during myocardial ischemia-reperfusion injury, associated with mitochondrial protection and apoptosis reduction. Circulation 2002;106:I270-I276.

35 Ahn HJ, Kim KI, Kim G, Moon E, Yang SS, Lee JS: Atmospheric-pressure plasma jet induces apoptosis involving mitochondria via generation of free radicals. PloS One 2011;6:e28154.

36 Xue L, Li M, Chen T, Sun H, Zhu J, Li X, Wu F, Wang B, Li J, Chen Y: PEinduced apoptosis in SMMC7721 cells: involvement of Erk and Stat signalling pathways. Int J Mol Med 2014;34:119-129.

37 Wu H, Ye M, Yang J, Ding J, Yang J, Dong W, Wang X: Nicorandil Protects the Heart from Ischemia/ Reperfusion Injury by Attenuating Endoplasmic Reticulum Response-induced Apoptosis Through PI3K/ Akt Signaling Pathway. Cell Physiol Biochem 2015;35:2320-2332.

38 Oakes SA, Scorrano L, Opferman JT, Bassik MC, Nishino M, Pozzan T, Korsmeyer SJ: Proapoptotic BAX and BAK regulate the type 1 inositol trisphosphate receptor and calcium leak from the endoplasmic reticulum. Proc Natl Acad Sci USA 2005;102:105-110.

39 Jiang X, Wang X: Cytochrome-c-mediated apoptosis. Annu Rev Biochem 2004;73:87-106.

40 Chinda K, Chattipakorn S, Chattipakorn N: Cardioprotective effects of incretin during ischaemiareperfusion. Diab Vasc Dis Res 2012;9:256-269.

41 Lorber D: GLP-1 receptor agonists: effects on cardiovascular risk reduction. Cardiovasc Ther 2013;31:238249.

42 Mundil D, Cameron-Vendrig A, Husain M: GLP-1 receptor agonists: a clinical perspective on cardiovascular effects. Diab Vasc Dis Res 2012;9:95-108.

43 Ravassa S, Zudaire A, Carr RD, Diez J: Antiapoptotic effects of GLP-1 in murine HL-1 cardiomyocytes. Am J Physiol Heart Circ Physiol 2011;300:H1361-1372.

44 Wei Y, Mojsov S: Tissue-specific expression of the human receptor for glucagon-like peptide-I: brain, heart and pancreatic forms have the same deduced amino acid sequences. FEBS letts 1995;358:219-224.

45 Korner M, Stockli M, Waser B, Reubi JC: GLP-1 receptor expression in human tumors and human normal tissues: potential for in vivo targeting. J Nucl Med 2007;48:736-743.

46 Saraiva FK, Sposito AC: Cardiovascular effects of Glucagon-like peptide 1 (GLP-1) receptor agonists. Cardiovasc Diabetol 2014;13:142. 